\title{
Implementation of Good Corporate Governance Principles in State-Owned Enterprises (BUMN) PT.PLN Indonesia
}

\author{
Edwin Purwanto \\ Student of Magister Management, Perbanas Institute \\ Jakarta, Indonesia
}

\begin{abstract}
For the last few decades, Good Corporate Governance (GCG) has become a strategic position within the company. There are two beliefs underlying that. First, GCG is the key to the company's success to grow and provide long-term benefits and to be able to win competition in the business world. Second, the poor implementation of GCG in the business sector is causing failure. Good Corporate Governance is a system that has the task of aligning the company's vision and mission with the management of the company.
\end{abstract}

GCG implementation in a good company must have four basic principles namely transparancy, accountability, responsibility, Independence, and fairness. The purpose of this research is to find out the implementation of GCG in state-owned enterprises (Government-Owned Enterprises) pt. PLN Indonesia by collecting data from the 2019 annual report of PT.PLN.

Keywords:- Implementation, Good Corporate Governance, State-owned Enterprises (BUMN) PT.PLN INDONESIA.

\section{INTRODUCTION}

The implementation of Good Corporate Governance (GCG) in the management of the company is very important because it directly provides clear instructions for the company to make informed and responsible decisions and enables the management of the company more safely, so as to increase the value of the company, the trust of business partners and the community.

The State Electricity Company (abbreviated PLN) or its official name is PT.PLN (Persero) is a state-owned enterprise that manages all aspects of electricity in Indonesia.

State-Owned Enterprises are state-owned enterprises that aim to provide services or kites to the public as well as provide income that will be used to organize the public interest. The capital of state-owned enterprises is largely controlled by the government and also the integrity of stateowned enterprises is also used for the benefit of many people. State-owned enterprises are also state assets because the state's wealth is in state-owned enterprises.
State-owned enterprises have a sense of being a business entity, where the capital is owned by the government derived from the wealth of the State. This corresponds to the Statute Number 19 of 2003.

In the economic system, the role of state-owned enterprises as economic actors applies nationally. The purpose of the establishment of state-owned enterprises is to realize the welfare of the community, as well as to meet the needs of the people in various sectors. Some sectors such as agriculture, fisheries, transportation, telecommunications, trade, electricity, finance to construction.

In 2002 the Government of Indonesia through the Ministry of State-Owned Enterprises began to introduce Good Corporate Governance through the Decree of the Minister of State-Owned Enterprises No. Kep117/MMBU/2002 dated August 1, 2002 on the Implementation of Good Corporate Governance Practices in State-Owned Enterprises. This regulation emphasizes the obligation for state-owned enterprises to implement Good Corporate Governance consistently and or make the principle of Good Corporate Governance as the basis of its operations, which is essentially aimed at improving the success of the company's business and accountability in order to realize shareholder value in the long term while paying attention to the interests of other stakeholders, and based on legislation and ethical values. State-Owned Enterprises (STATEOWNED ENTERPRISES) is the main target of the Government of Indonesia to be able to apply the principles of good corporate governance or Good Corporate Governance. This is supported by the opinion of Kaihatu (Kaihatu, 2006), which states that state-owned enterprises are the main players in the Indonesian economy. Through the Regulation of the Minister of State-Owned Enterprises Number: PER - 01 /MBU/2011 on the Implementation of Good Corporate Governance in State-Owned Enterprises, emphasizing the obligation for state-owned enterprises to implement Good Corporate Governance consistently and or making the principles of Good Corporate Governance as the foundation of its operations, which is basically aimed at improving business success and corporate accountability in order to realize shareholder value in the long term while paying attention to the interests of other stakeholders. The implementation of Good Corporate Governance is necessary so that the company can be managed properly, efficiently, professionally, and not harm the interests of stakeholders. 


\section{LITERATURE REVIEW}

\section{$>$ Definition of Good Corporate Governance (GCG)}

Good Corporate Governance is a good principle that underlies the process and management of companies based on regulations, laws, and business ethics. According to experts on the definition of GCG is Cadbury Commitee, GCG is a system that governs the relationship between stakeholders (shareholders, company management, creditors, government, and other related parties) who have certain rights and obligations to the company. Effendi in his book "The Power of Good Corporate Governance" states that the definition of GCG is an internal control order or system of a company that aims to manage significant risks in order to meet business objectives, and that is done by securing assets and increasing the investment value of shareholders over a long period of time.

In Indonesia the definition of Governance is often translated as "arrangement" as for in the context of Good Corporate Governance is often also called "governance". From the above definition it can be concluded that Good Corporate Governance is:

1. Structure that regulates harmonious relationship patterns about the role of the Cosmisaris Board, Board of Directors, General Meeting of Shareholders (GMS) and other stakeholders.

2. The check and balance mechanism includes consideration of authority over corporate control that can limit the appearance of two opportunities: mismanagement and misuse of the company.

3. Transparent process of determining the company's objectives, achievement and measurement of performance.

According to Mas Achmad Daniri in his book entitled Lead By GCG he argues that there are important aspects of GCG that need to be understood by various business people namely:

1. There is a balance of relationships between the organs of the company including the General Meeting of Shareholders (GMS), the Board of Commissioners, and the Board of Directors.

2. Fulfillment of corporate responsibility as a business entity in the community to all stakeholders.

3. The rights of shareholders to be informed properly and correctly at the time necessary regarding the company.

4. Equal treatment of shareholders.

In the Regulation of The Minister of State-Owned Enterprises NO: PER-01/MBU/2011 GCG is Good Corporate Governance, hereby called GCG are the principles underlying a process and mechanism of corporate management based on the regulation of legislation and ethics of trying. GCG principles consisting of transparency, accountability, responsibility, independence, and fairness are required to realize the company's business continuity by taking into account stakeholders (Bambang Gunawan \& Budiarjo, 2014; Burak, Erdil, \& Altindağ, 2017; Lidiyawati, 2016; Wakarmamu, 2015).

\section{Principles of Good Corporate Governance (GCG)}

In principle Good Corporate Governance (GCG) has five principles commonly referred to as TARIF, namely: 1. Transparency

Transparency bias is defined as openness of information, both in decision making and in disclosing material information and relevant company activities. According to the capital market regulations in question material and relevant information is information that can influence decision making and policy.

In realizing such transparency the company must provide sufficient, accurate, and timely information to some interested parties with such companies. Each company is expected to publish financial information as well as other information that is material and impacts on the company's performance.

\section{Accountability}

Accountability is the clarity of the functions, structure, system and accountability of the company's organs so that the processing of the company is carried out well and effectively. If the principle of accountability is applied effectively, then there is clarity on the functions, rights, obligations, authorities and responsibilities between the GMS, Board of Commissioners and board of directors. With this clarity, the company will be spared the agency problem (conflict of interest role).

\section{Responsibility}

Responsibility perusahaan adalah kesesuaian (kepatuhan) didalam pengelolaan perusahaan terhadap prinsip korporasi yang sehat serta peraturan perundangn yang berlaku. Peraturan yang dimaksud adalah yang berkaitan dengan pajak, hubungan industrial, perlindungan lingkungan hidup, kesehatan / keselamatan kerja, standar penggajian, dan persaingan yang sehat.

For example, food companies in Indonesia must have halal certificate on each product produced. This is a form of responsibility to the community. Through HALAL certificate in terms of consumers, they feel safe and confident to consume the food products.

\section{Independency}

Independency is the most important principle in the implementation of Good Corporate Governance in Indonesia. Independency is a situation in which the company is managed professionally without conflict of interest and influence / pressure from any party that is not in accordance with the prevailing laws and principles of a healthy corporation. The principle of independency is very important especially in the decision-making process. The loss of the principle of independence will lead to a loss of objectivity in the decision-making.

\section{Fairness}

Fairness can be defined as fair and equal treatment in fulfilling stakeholder rights arising under the agreement and applicable laws and regulations. Fairness includes clarity on the rights of financiers, the legal system and enforcement of 
ISSN No:-2456-2165

regulations to protect the rights of minority shareholders from various forms of fraud.

\section{Good Corporate Governance (GCG) Implementation Strategy \\ The hardest thing in implementing Good Corporate} Governance (GCG) is formulating and communicating the company's vision, mission, value, and scope of business goals and strategies to all people in the company, so that no one does not understand the direction of the company's objectives.

Based on best practices the company should be able to separate management functions from company ownership. In accordance with Law No. 40 of 2007 concerning Limited Liability Company as a corporate legal system in Indonesia, the governance structure of limited liability company (PT) adheres to the Two Board System, namely the Board of Directors and Board of Commissioners. Thus a limited perserpoan has three organs, namely:

1. RUPS.

2. Board of Commissioners.

3. Board of Directors.

The three organs do not carry each other, but have an equally important role and authority to create a check and balance mechanism that can run effectively.

\section{Implementation Phase of Good Corporate Governance (GCG)}

\section{Preparation}

This stage consists of:

- Awareness Building is an initial socialization step to build awareness about the importance of Good Corporate Governance (GCG) and its shared commitment in its implementation.

- Good Corporate Governance (GCG) Assessment is an effort to measure or map the company's condition in the implementation of Good Corporate Governance (GCG).

- Good Corporate Governance (GCG) Manual Building is a step taken after Good Corporate Governance (GCG) Assessment to draw up implementation guidelines for Good Corporate Governance (GCG) manual implementation.

\section{Implementation}

This stage consists of:

- Socialization.

- Implementation.

- Internalization.

\section{Evaluation}

The evaluation stage is a stage that needs to be carried out regularly to measure the effectiveness of the implementation of Good Corporate Governance (GCG) which has been done by asking independent parties to audit the implementation and scoring of good corporate governance (GCG) practices that have been carried out by the company.

\begin{tabular}{|c|c|}
\hline $\begin{array}{l}\mathrm{V}_{1} \\
\text { Implementation: } \\
\begin{array}{ll}\text { 1. } & \text { Socialization. } \\
\text { 2. } & \text { Implementation. } \\
\text { 3. } & \text { Internalization. }\end{array}\end{array}$ & $\begin{array}{l}\text { Hypothesis: } \\
\mathrm{H}_{1} \text { Company System } \\
\mathrm{H}_{2} \text { Company Regulation and } \\
\text { Guideline }\end{array}$ \\
\hline & $\mathrm{H}_{3}$ Compliance of State Law \\
\hline \begin{aligned} \multicolumn{1}{l}{$\mathrm{V}_{2}$} & \\
TARIF: & \\
1. & Transparency \\
2. & Accountability \\
3. & Responsibility \\
4. & Independency \\
5. & Fairness \end{aligned} & $\begin{array}{l}\mathrm{H}_{4} \text { Balance of Rights and } \\
\text { Responsibilities } \\
\mathrm{H}_{5} \text { Company's Internal and } \\
\text { External Positive Values } \\
\text { 1. }\end{array}$ \\
\hline
\end{tabular}

Fig 1:- Thinking Framework

\section{RESEARCH METHOD}

The research used is qualitative that is descriptive and tends to use analysis. The foundation of the theory is used as a guide to focus research according to the facts in the field. In addition, the foundation of this theory is also useful to provide an overview of the background of the research and as a discussion of the results of the research. In this study the object used is the Company Report 2019 PT. PLN Indonesia which from the Report is analyzed by comparing the theory with the company's work to know the effectiveness of the implementation of tariff principles good corporate governance.

\section{DISCUSSION}

In order to strengthen the implementation of GCG and clarify guidance for pln management and employees working within the GCG corridor, during 2019 the Company issued various new policies and guidelines as well as improvements to existing documents.

As a manifestation of PLN's commitment to implement GCG in full, the Company has had GCG guidelines (GCG Code) as well as various policies that are updated periodically to be tailored to best practices in the business environment, the company's business conditions and business development as well as changes to various applicable laws and regulations. These guidelines and policies include:

1. Good Corporate Governance Guidelines.

2. Board Manual or Work Procedure of the Board of Commissioners and Board of Directors.

3. Internal Supervision Charter.

4. Internal Supervision Charter.

5. Charter of the Committee of the Board of Commissioners.

6. Risk Management Manual.

7. Procurement Guidelines for Goods and Services.

8. Violation Reporting System.

9. LHKPN Reporting Policy.

10. Corporate Financial Transaction Policy (Inside Transaction Policy).

11. Gratification and Conflict of Interest Prevention Policy.

12. Organizational Guidelines.

13. Business Portfolio Management Policy. 
To strengthen GCG implementation, throughout 2019 the Company issued various policies and carried out activities to strengthen the organization, improve service to customers, and improve internal control tools as described below:

1. Socialization of The Company's Code of Conduct and Business Ethics.

2. Renewal of Procurement Guidelines for Goods and Services with Board of Directors Regulation No. 0164.P/DIR/2019.

3. Renewal of Risk Management Implementation Guidelines with PERDIR (Board of Directors Regulation) No. 0117.P/DIR/2019 and determination of PERDIR No. 0119.P/DIR/2019 on Mechanisms for Preparation and Monitoring of Risk Assessment for Activities and Draft Decisions.

4. Determination of PERDIR (Board of Directors Regulation) No. 0196.P/ DIR/2019 on The Implementation of Governance, Risk Management and Compliance (GRC).

5. Determination of PERDIR (Board of Directors Regulation) No. 0121.P/DIR/2019 on Anti Fraud Policy in the Environment of PT PLN (Persero).

6. Determination of Board of Directors Guidelines No. 0122.P/DIR/2019 on Management of Conflicts of Interest in the Environment of PT PLN (Persero).

7. Implementation of GAP Analysis SNI ISO 37001:2016 on Anti-Bribery Management System.

8. Changes to PERDIR (Board of Directors Regulation) No. 0051.P/DIR/2018 on The Organization and Working Procedures of PT PLN (Persero).

9. Second Amendment to PERDIR (Board of Directors Regulation) No. 0051.P/DIR/2018 on Organization and Working Procedures of PT PLN (Persero).

Implementation of TARIF principles carried out by PT. PLN is as follows:

\section{$>$ Transparency}

As one of the tangible forms of GCG implementation, PLN implements a whistleblowing mechanism to prove the Company's commitment to transparency, accountability, and reliability aspects. Whistleblowing mechanism is part of efforts to prevent and eradicate corruption, bribery, and other fraudulent practices to improve the quality of GCG implementation in pln environment. As one of the most important and largest state-owned enterprises in Indonesia, GCG practices in PLN will certainly be a concern and a benchmark of GCG practices in other state-owned enterprises or similar corporations. Therefore, it is important to ensure that operational activities in PLN run without KKN practices in order to maintain the trust of business partners and stakeholders.

The scope of whistleblowing mechanism implementation involves all components and stakeholders to jointly keep business activities free from despicable actions. This system accommodates reports from internal and external parties of the Company, provides various complaint channels that are easy to reach, ensures the confidentiality of the whistleblower's identity and provides protection for whistleblowers in the event of retaliation from the report or the agency.

> Goals:

1. Create a conducive working climate,

2. Transparency in the implementation of tender activities,

3. Improving the quality of financial management,

4. Prevention of violations that may cause financial or nonfinancial losses that may damage pln's image.

\section{$>$ Accountability}

Anti-Bribery Management System (SMAP). Pt. PLN is pioneering the implementation of anti-bribery management system (SMAP) or known as ISO 37001:2016. SMAP is the Company's effort to prevent the practice of giving and receiving bribes of any kind as well as various other forms of corruption. With this system is expected to emerge a culture of honesty, openness, and compliance as the basic value of business activities. The Company added one important element in the implementation of five basic principles of GCG, namely the integrity element developed through the concept of PITA (Participation, Integrity, Transparency and Accountability). PITA is one of the important foundations in improving the integrity of the entire PLN board with the main goal of preventing and minimizing the possibility of fraud and corruption.

Business Portfolio Management Policy. The Company has the Business Portfolio Management Guidelines set forth in Perdir No. 1780.P/DIR/2018 as guidelines for aligning the direction and strategy of PLN's business portfolio management and subsidiaries in order to provide added value for PLN Group as a whole, clarify the accountability of interactions between PLN as a parent company and subsidiaries, increase synergy between PLN Group as a whole and conduct pln business portfolio management by applying GCG principles. PLN's business portfolio management mission is known as SOLID (Securing Business Sustainability, Optimizing Cost Efficiency, Leading Industry Capability, Increasing Profit Contribution and Developing New Edge).

\section{$>$ Responsibility}

In accordance with Law of the Republic of Indonesia No. 40 of 2007 on Limited Liability Company (Law 40/2007), the overall governance structure in PLN consists of the main organs of the Company consisting of the General Meeting of Shareholders (GMS), Board of Directors and Board of Commissioners. Each organ has functions, roles and responsibilities in the implementation of GCG in the Company.

Based on Law No. 40 of 2007 on Limited Liability Company, PLN and other business sectors are also mandated to organize social and environmental responsibilities and implement community empowerment programs through the Partnership and Community Development Program. 
PLN has committed to making electricity as a medium to improve people's quality of life, seek electricity to be the driver of economic activities and to carry out environmentally minded business activities. The commitment is realized through the involvement of various parties in designing, implementing, and evaluating the Company's Social and Environmental Responsibility (TJSL) activities. The Company's Board of Directors has clearly formulated tjsl's vision and mission as follows.

\begin{tabular}{|c|c|}
\hline VISION & MISSION \\
\hline $\begin{array}{c}\text { To make TJSL PT PLN } \\
\text { (Persero) leading in }\end{array}$ & $\begin{array}{c}\text { To carry out social activities } \\
\text { to help bridge all stakeholder } \\
\text { interests of the Company in } \\
\text { improving electricity needs } \\
\text { while paying attention to the } \\
\text { harder to be synergistically in } \\
\text { order to advance the } \\
\text { and the environment. }\end{array}$ \\
Company's image. \\
\hline
\end{tabular}
Table 1

Initially, social responsibility had various forms and variants based on the point of view of each corporation. Until finally in 2010, the International Standard Organization (ISO) formulated a pakem known as ISO 26000 Social Responsibility (SR). The ISO 26000 SR standard is a guide that is expected to encourage the business sector and other organizations to practice social responsibility to have a positive impact on workers, communities, and the environment.

In principle, there are several elements in the ISO 26000 SR standard that have long been integrated in tjsl aspects owned by the Company, including:

1. CSR Principles are Accountability, Transparency, Ethical Behavior, Respecting Stakeholder Interests, Respecting Legal Supremacy, Respecting International Norms, and Respecting Human Rights.

2. Recognition of social responsibility and stakeholder engagement.

3. The fulfillment of core subjects and isuisu is relevant to social responsibility. For each core subject, it will be assessed the extent of PT. PLN has fulfilled the relevant actions and expectations set out in the.

TJSL activities are carried out by each work unit. The source of funds to finance activities is budgeted in the Company's Work Plan and Budget (RKAP).

\section{$>$ Independency}

The Board of Commissioners is an Organ of the Company that has the task of supervising and advising on the course of the Company conducted by the Board of Directors. The Board of Commissioners is collectively collegial, meaning it is an organ in the form of an assembly and each Commissioner cannot act alone without a complete decision of the Board of Commissioners. The Board of Directors is the Company's Organ authorized and fully responsible for the management of the Company for the benefit of the Company, in accordance with the company's objectives and objectives and representing the Company, both inside and outside the court in accordance with the provisions of the Articles of Association. The main duties of the Board of Directors are to lead and manage the Company by constantly trying to improve the efficiency and effectiveness of the Company, as well as take care of the Company's assets.

Furthermore, each member of the Board of Directors signs an integrity pact at the beginning of each year and each will carry out certain corporate actions to declare its independence status for the management of the Company in general and for the actions/actions of the corporation. The Corporate Secretary is tasked with ensuring that this practice has been implemented in accordance with GCG principles.

In carrying out the roles and functions of the management of the company as well as managing relations with the Board of Commissioners, the Board of Directors refers to the Working Guidelines of the Board of Commissioners and Board of Directors (Board Manual). Board Manual contains instructions for the implementation of the work of the Board of Commissioners and Board of Directors and explains the stages of activity in a structured, systematic, easy to understand and can be carried out consistently, can be a reference for the Board of Commissioners and Board of Directors in carrying out their respective duties to achieve the Company's Vision and Mission.

\section{Fairness}

Ensuring fairness and Equality in the workplace. PLN recognizes that the Company must ensure fairness and equality in the workplace. So in carrying out all its business, the Company applies the principles of openness, fairness, equality and fairness without distinguishing the tribe, religion, race, class and gender in the Company's environment. To make this happen, the Company implements anti-discrimination practices in human resources management starting from employee recruitment process, performance assessment, remuneration, to competency development and career level.

As a form of the Company's commitment to creating fairness and equality in the workplace, the Company establishes an Employee Performance Management System (SIMKP) in evaluating individual performance and performance-based Remuneration Systems.

\section{CONCLUSION}

After conducting research on the implementation of Good Corporate Governance and Tariff Principles it can be concluded that:

1. PT. PLN has a company system that arguably has the standard of a large company.

2. PT. PLN has Company Regulations and Company Guidelines that can be seen from the Good Corporate Governance Guidelines, Board Manual or Work Procedures of the Board of Commissioners and Board of Directors, Internal Supervision Charter, Corporate Code of Conduct and Business Ethics, Charter of the Board of Commissioners Committee, Risk Management Manual, 
Procurement Guidelines for Goods and Services, Violation Reporting System, LHKPN Reporting Policy, Corporate Financial Transaction Policy (Internal Transaction Policy), Gratification and Conflict of Interest Prevention Policy, Organizational Guidelines, Business Portfolio Management Policy.

3. PT. PLN in conducting its business has also complied with the applicable Laws of the State in Indonesia.

4. The creation of a balance between Rights and Responsibilities can be seen from the Board Manual or Work Procedures of the Board of Commissioners and Board of Directors, The Charter of Internal Supervision, The Company's Code of Conduct and Business Ethics, the Charter of the Board of Commissioners Committee, the Risk Management Manual.

5. The Company's Internal and External Positive Values can be seen from the public's trust in using electricity services provided by PLN as well as employee welfare.

Conclusion of PT. PLN, which implements tariff principles and good corporate governance, has a good impact on the company and long-term business continuity.

\section{REFERENCES}

[1]. Daniri, Mas Achmad. (2005a). Good Corporate Governance: Konsep dan Penerapannya dalam Konteks Indonesia. Jakarta: Ray Indonesia.

[2]. Daniri, Mas Achmad. (2014b). Lead By GCG. Gagas Bisnis Indonesia. Jakarta.

[3]. Lukviarman, Niki. (2016). Corporate Governance. Solo: Era Adicitra Intermedia.

[4]. Sutedi, Adrian. S.H., M.H. (2011) Good Corporate Governance. Jakarta, Sinar Grafika.

[5]. Sutojo dan Altridge, E. J. (2008) Good Corporate Governance Tata Kelola Perusahaan yang Sehat. Jakarta, Damar Mulia Pustaka.

[6]. Keputusan Menteri Badan Usaha Milik Negara Nomor: Kep-117/M-MBU/2002 Tentang Penerapan Praktek Good Corporate Governance Pada Badan Usaha Milik Negara (BADAN USAHA MILIK NEGARA).

[7]. Keputusan Menteri Pendayagunaan Aparatur Negara Nomor 63 tahun 2003 (63/Kep/M,Pan/7/2003) Tentang Pedoman Umum Penyelenggaraan Pelayanan Publik. 